\title{
A Domain Model for Capturing Knowledge of the Lean Approach
}

\author{
Younes Tiamaz ${ }^{1}$ (D), Nissrine Souissi² (iD \\ ${ }^{1}$ Mohammed V University (Morocco) \\ ${ }^{2}$ Mines-Rabat School (Morocco) \\ y.tiamaz@gmail.com,souissi@enim.ac.ma
}

Received: May 2018

Accepted: December 2018

\section{Abstract:}

Purpose: The literature offers many definitions of the Lean but it lacks a standard definition that would facilitate its implementation. These definitions are closely related to the specificities of the domain, sector or problem studied. The purpose of this paper is to capture the concepts of the Lean to propose a generic definition independent of the application domain.

Design/methodology/approach: Eighteen Lean systematic literature reviews in different domains have been studied in this paper to understand the Lean and capture the concepts thoroughly. These reviews reviewed a total of more than 2171 articles.

Findings: This paper presents a new reading of the Lean. A Lean domain model has been established to represent the concepts and their interactions.

Research limitations/implications: This research is limited by the papers indexed in the Scopus database and presenting a systematic literature review.

Originality/value: A reference model of the Lean lacks in the literature. The proposed domain model clarifies the Lean and provides a holistic view that is valid in all domains.

Keywords: Lean approach, process management, improvement, domain model, knowledge, UML

\section{To cite this article:}

Tiamaz, Y., \& Souissi, N. (2019). A domain model for capturing knowledge of the Lean approach. Journal of Industrial Engineering and Management, 12(1), 83-96. https://doi.org/10.3926/jiem.2660

\section{Introduction}

Lean manufacturing was originally developed in Japan by Toyota, where it was known as the Toyota Production System (Herron \& Hicks, 2008). Krafcik (1988) is the first who used the term Lean in an attempt to generalize Toyota's work but it was thanks to Womack, Jones and Roos (1990), the term "Lean manufacturing" or "Lean production" became favorite for designating the Toyota production system as a new manufacturing paradigm unlike Fordism (Danese, Manfè \& Romano, 2018; Henrique \& Filho, 2018). Although the Lean concept was born more than 20 years ago, the attraction of the Lean as a field of research continues to grow (Danese et al., 2018). 
The primary objective of the Lean approach is to produce better quality products at the lowest cost and in less time by eliminating waste (Dennis, 2007; Liker, 1997). Lean is a process improvement approach used to deliver products and services more efficiently, faster and at a lower cost (Laureani \& Antony, 2017). It is considered the new most influential paradigm in the industrial domain (Forrester, Kazumi-Shimizu, Soriano-Meier, -Garza-Reyes \& Cruz-Basso, 2010). Lean research, application and thinking have evolved from the Japanese automotive industry into a holistic value system applicable to all business sectors, both private and public (Samuel, Found \& Williams, 2015).

Lean is based on five main principles: defining the value, identifying the value chain for each product/service, identifying waste, promoting continuous flows, introducing pull flow, seeking perfection (Womack \& Jones, 2003). Afterwards, Liker (2004) proposed 14 Lean principles and grouped them into 4Ps: "Philosophy"; "Process"; "People and Partners"; and "Problem Solving".

There are over a hundred Lean practices available and practiced by industries (Pavnaskar, Gershenson \& Jambekar, 2003; Rose, Deros, Rahman \& Nordin, 2011). Various interpretations have explicitly evolved to "lean" and its philosophy, principles, and related measures (Stone, 2012a). Hines, Holweg and Rich (2004) pointed out that the researchers use various definitions for the Lean term, so there is no standard terminology.

Literature presents significant studies on the Lean (Belayutham, González \& Yiu, 2016; Collar, Shuman, Feiner, McGonegal, Heidel, Duck et al., 2012; Duska, Mueller, Lothamer, Pelkofski \& Novicoff, 2015; Rohani \& Zahraee, 2015; Sutari, 2015). Many companies can successfully implement the Lean approach, but others have not achieved the expected results (Bhasin \& Burcher, 2006; Staats, Brunner \& Upton, 2011). Dombrowski and Mielke (2013), Liker, Convis and Meskimen (2014) and Orr (2005) also reported that the businesses achieve significant results by implementing the Lean tools only in Lean's early years, and improvements stagnate sooner or later. Casey (2009) reported that the traditional Lean paradigm is reflected in nearly two-thirds of failed implementations, while only $16.67 \%$ of implementations can achieve sustainable results - less than twelve months though.

This failure is due mainly to the definition of the Lean, which is very elusive and the lack of a clear definition has many consequences for practitioners seeking to implement Lean as well as researchers attempting to capture its essence (Pettersen, 2009). Also, Mostafa, Dumrak and Soltan (2013) highlighted that the main reason of unattainability of the lean benefits is the incomplete understanding of the lean concepts and the purpose of the lean practices.

Lean has evolved in the industry and has subsequently been adopted by other domains, but the term "Lean" and its association with the techniques of "Japanese management" has created confusion and difficulties when discussing the topic outside the industrial domain (Stone, 2012a).

The Lean concepts have not been fixed in time but have been evolved over the years, including new issues, new contexts of implementation, and new dimensions (Danese et al., 2018). For this reason, the definitions of Lean are always related in some way to the target environment and the understanding of the authors of the Lean. This explains the ambiguity surrounding this approach, which results in the failure of several companies to achieve their desired objectives.

The purpose of this paper is to clarify Lean by studying its behavior and the interactions with its concepts. Moreover, present these associations in a domain model using the UML modeling language. The development of this model consists in following the three steps: (i) The identification of the concepts; (ii) The identification of the relations between them; and (iii) the construction of the domain model.

The paper is structured in six sections. Section 2 presents Research methodology. Section 3 presents the definitions of the Lean approach proposed in the literature. Section 4 presents the proposed domain model. The use of this model in the construction of a Lean method is illustrated in section 5. Conclusions and future research are given in Section 6 . 


\section{Research Methodology}

The method illustrated in Figure 1 was followed to construct the domain model. It consists of four steps, namely: (1) Literature review of the Lean models; (2) Capturing the Lean concepts, (3) Defining the relations between the Lean concepts captured; and finally (4) Development of the Lean domain model.

(1) The first step represents a literature review of the Lean models (Tiamaz \& Souissi, 2017) and papers describing Lean to understand this approach. To conduct this literature review, the steps illustrated in Figure 2 were followed.

Two Research Questions guided in this literature review: (RQ1) Does the literature present a standard definition of Lean? (RQ2) Is there a reference domain model that describes Lean?

For the first research question (RQ1), No exclusion criterion was applied for the Lean application domain. All domains are included in this study. Also, papers that associate Lean with other process improvement approaches are also included. This decision is made to have a holistic view of the Lean approach as well as to analyze Lean interactions with other approaches. Next, the papers that are published in scientific journals from 2015 to 2018 were extracted and only the papers that present a systematic literature review of the Lean were chosen.

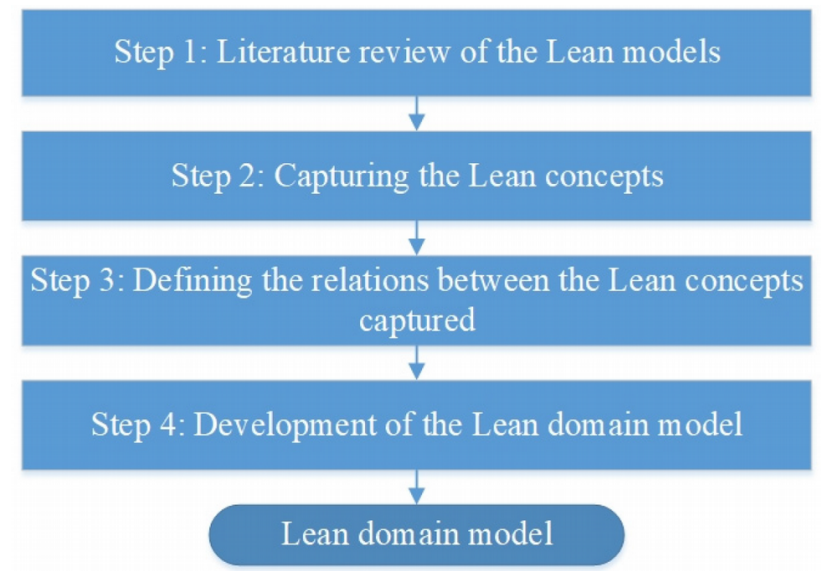

Figure 1. Lean domain model construction method

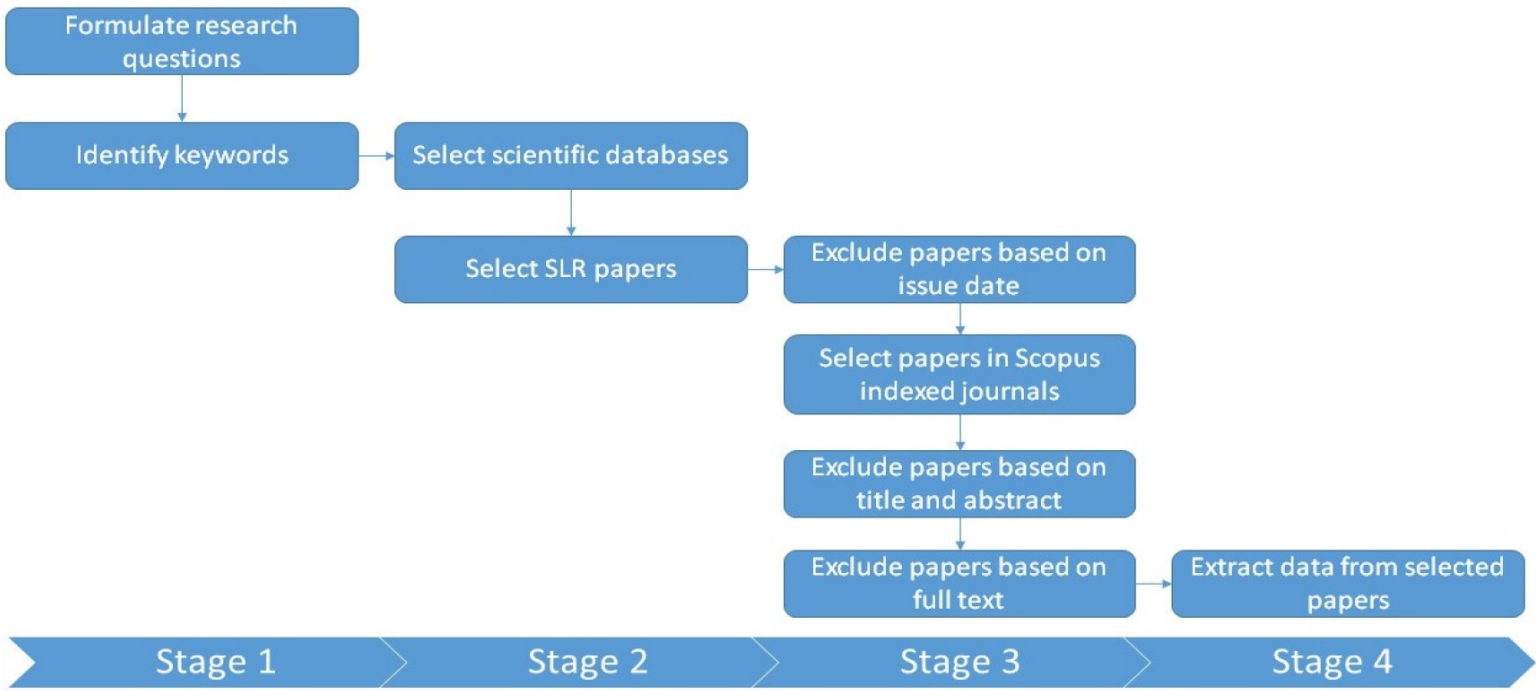

Figure 2. The literature review method 


\begin{tabular}{|c|c|c|c|}
\hline Journals & Articles (SLR) & $\begin{array}{l}\text { Number of } \\
\text { analyzed } \\
\text { articles }\end{array}$ & Period \\
\hline $\begin{array}{l}\text { International Journal of Quality \& } \\
\text { Reliability Management }\end{array}$ & $\begin{array}{l}\text { Albliwi, Antony, Halim-Lim \& van der } \\
\text { Wiele (2014) }\end{array}$ & 56 & $1995-2013$ \\
\hline \multirow{2}{*}{$\begin{array}{l}\text { International Journal for Quality in } \\
\text { Health Care }\end{array}$} & Moraros,Lemstra \& Nwankwo (2016) & 22 & 2009- 2014 \\
\hline & Woodnutt (2018) & 12 & 2009-2016 \\
\hline \multirow{2}{*}{ Journal of Cleaner Production } & Garza-Reyes (2015) & 59 & $1997-2015$ \\
\hline & Caldera, Desha, C. \& Dawes (2017) & 102 & $1996-2015$ \\
\hline \multirow{3}{*}{$\begin{array}{l}\text { International Journal of Lean Six } \\
\text { Sigma }\end{array}$} & Raja-Sreedharan \& Raju (2016) & 235 & $2003-2015$ \\
\hline & de Freitas \& Costa (2017) & 28 & 2004-2015 \\
\hline & Stone (2012a) & 234 & 1970-2009 \\
\hline Journal of Manufacturing Systems & Soliman \& Saurin (2017) & 94 & Until 2016 \\
\hline \multirow{2}{*}{$\begin{array}{l}\text { Total Quality Management and } \\
\text { Business Excellence }\end{array}$} & Laureani \& Antony (2017) & 179 & $1982-2015$ \\
\hline & Henrique \& Filho (2018) & 118 & $2004-2017$ \\
\hline Production Planning \& Control & $\begin{array}{l}\text { Cherrafi, Elfezazi, Garza-Reyes, } \\
\text { Benhid \& Mokhlis (2017) }\end{array}$ & 91 & $1996-2016$ \\
\hline \multirow{2}{*}{ Sustainability } & de Carvalho, Granja \& da Silva (2017) & 48 & $1998-2016$ \\
\hline & Tasdemir \& Gazo (2018) & 477 & $1998-2018$ \\
\hline $\begin{array}{l}\text { International Journal of Quality \& } \\
\text { Reliability Management }\end{array}$ & $\begin{array}{l}\text { Syltevik, Karamperidis, Antony \& } \\
\text { Taheri (2017) }\end{array}$ & 23 & $1998-2014$ \\
\hline $\begin{array}{l}\text { International Journal of } \\
\text { Technology Assessment in Health } \\
\text { Care }\end{array}$ & $\begin{array}{l}\text { Maijala, Eloranta, Reunanen \& Ikonen } \\
\text { (2018) }\end{array}$ & 11 & 2011-2016 \\
\hline $\begin{array}{l}\text { Journal of Health Organization } \\
\text { and Management }\end{array}$ & Aij \& Teunissen (2017) & 32 & $2000-2016$ \\
\hline \multirow{2}{*}{$\begin{array}{l}\text { International Journal of } \\
\text { Operations \& Production } \\
\text { Management }\end{array}$} & Bhamu \& Singh-Sangwan (2014) & 209 & $1988-2012$ \\
\hline & Samuel et al. (2015) & 141 & $1987-2013$ \\
\hline
\end{tabular}

Table 1. Analyzed articles (SLR)

The Scopus database is used as a search engine and the combination of "Lean" and "systematic literature review" is used as search keywords, which must be mentioned in the title. 48 papers were found after the use of these two keywords. In the second step, the abstract of each article was examined to retain it or reject it. Any disagreement between the authors was resolved by reading the complete paper.

Fifteen papers dealt mainly with Lean. Three papers published in Scopus indexed journals but were not found by the keywords used were included (see Table 1).To answer the second research question (RQ2), the same search engine is used and the same inclusion and exclusion criteria are kept. However, the publication date range from 2000 to 2018 is extended. This decision is based on the conclusion of Hines et al. (2004) who established a literature review on the Lean from 1980 until 2003 and pointed out that the Lean started to be interesting outside the industry in early 2000. Also based on the conclusion of Stone (2012a), he mentioned that Lean started to be interesting outside early 2001 after a systematic review of the Lean literature from 1990 to 2009. Also, Samuel et al. (2015), which analyzed Lean's evolution from 1987 to 2013, pointed out that since the year 2000 the adoption of Lean has increased considerably in all sectors.

The combination of the keywords "Lean" and "domain model" or "Lean" and "conceptual model" are used. These keywords are used in order to find articles that focus primarily on representing the Lean concepts in a model. 
(2) The second step involves capturing the Lean concepts. It is to identify the fundamental concepts that characterize it. This step is intended to be the most important in order to capture all the knowledge of the Lean.

(3) The third step is to emphasize the different relations between the captured concepts, as their identification is not enough to build a domain model. This step enables to define the rules that control the relationships between the captured concepts.

(4) The fourth step is to build the Lean domain model based on the Lean concepts captured and the relations between them identified in the previous steps.

\section{Lean Understanding in the Literature}

Lean is a set of operational philosophies, leadership and management practices, as well as tools that can help create maximum value by reducing sources of waste in a process (Maijala et al., 2018). In recent years, Lean has been implanted in various fields. Several studies have provided empirical evidence of Lean's benefits regarding time, productivity, quality, and other business dimensions, but most of these studies are from industry (Soliman \& Saurin, 2017). However, there are enormous opportunities for using the Lean in all other domains (Syltevik et al., 2017).

Samuel et al. (2015) have identified that the searchers consider future research the Lean: as a generic representation of TPS, as a process improvement method for an organization and a follow-up polarized body of academic literature that has developed over time. However, Stone (2012a) emphasized that the orientation of the authors change over time. He identified five phases: Discovery phase; Dissemination phase; Implementation phase; Enterprise Phase; and performance phase.

Although Lean improves operational efficiency, improves employees' self-confidence, long-term financial benefits, and improves the quality of service provided (Syltevik et al., 2017), the majority of studies postpone the failure of the Lean implementation in different domains and different countries (Albliwi et al., 2014). In the same context, Soliman and Saurin (2017) concluded that the Lean encounters several limitations (i.e., there is no clear differentiation between waste and value-added) in complex systems (i.e., Hospital). Also, Moraros et al. (2016) reported that no statistically significant association between Lean and client satisfaction suggests that the Lean improves quality in the hospital setting. Thus, they emphasized that it has a negative influence on employee satisfaction and financial costs.

In the hospital domain, Henrique and Filho (2018) found that the majority of the work cited no continuous improvement methodology to carry out their implementations, they also stressed that the Lean is the continuous improvement approach with the most significant number of articles without any methodology to follow. Moreover, a few articles, describing some aspects of sustainability, described the situation after 24 months of Lean implementation. They also pointed out that the majority of the articles analyzed tend to apply Lean in a limited context, but this contradicts the holistic view defended by many authors in the literature. It is concluded that the Lean practices and principles have not yet been well defined and reported in the hospitals. It seems that the concept of the Lean has been misunderstood in the hospital domain (Maijala et al., 2018).

Furthermore, in view of the fact that case studies only use tools such as 5S, VSM, Kaizen, etc. to implement Lean (Bhamu \& Singh-Sangwan, 2014), It is essential for Lean practitioners to understand the type of tools that can be used to improve quality (Syltevik et al., 2017). On the other hand, Henrique and Filho (2018) stated that there is an immediate need for empirical research in the hospital domain, which describes not only the tools that have been applied and the results that have been achieved, but also how have been executed. Henrique and Filho (2018) indicated that future research could explore the relations between the non-use of a methodology and the loss of sustainability and the failures of the Lean implementation.

There is no unique definition for Lean. Also, there is no formal definition (Samuel et al., 2015). Bhamu and Singh-Sangwan (2014) Found 34 definitions between 1988 and 2012. The majority of the literature reviews analyzed in this paper indicated that after 2010 the publications that focused on Lean have increased and for this purpose, other definitions of Lean have been proposed in the literature and can be multiplied in the future. 
Bhamu and Singh-Sangwan (2014) emphasized that the application of the Lean in different sectors, with different objectives leading to various or even divergent definitions. Lean can be considered as "a way"; "a process"; "a set of principles"; "a set of tools and techniques"; "an approach"; "a concept"; "a philosophy"; "a practice"; "a system"; "a program"; "a manufacturing paradigm"; or "a model". Lean can be considered as a strategy (Cherrafi et al., 2017) or methodology (Laureani \& Antony, 2017; Tasdemir \& Gazo, 2018).

Tiamaz and Souissi (2017) have analyzed the Lean models and concluded that these Lean models interpret the Lean in different ways. They proposed two types of classification of these models. The first classification is based on objectives, principles and tools. The second classification is based on the scope that can be generic or specific (for a domain, a sector or a problem).

The objectives of the Lean should be clearly explained to employees as well as the Lean principles which are factors helping to well implement the Lean (Aij \& Teunissen, 2017). However, how is it possible to ensure these success factors if there is no clear and unique definition of the Lean?

Furthermore, the lack of a standard definition of the Lean also generates different definitions when the Lean is combined with other approaches. Taking Lean Six Sigma as an example, Raja-Sreedharan and Raju (2016) analyzed 235 papers between 2003 and 2015 and found 46 definitions of Lean six sigma. In addition, they found that the Lean Six Sigma can be considered as "Approach", "Methodology", "Model", "Philosophy", "Program", "Strategy" or "System".

There are several readings of the Lean. It is apprehended according to the viewpoint of the process manager, which presents a risk of underestimating, or overestimating the capabilities of the Lean. Therefore, defining all the knowledge of the Lean in a domain model can help clarify it.

\section{Lean Domain Model}

Tiamaz and Souissi (2018) focused on the Lean implementation and found that the majority focuses mainly on tools and considers that implementing Lean is to use only a set of tools. In order to take into account all the knowledge of the Lean when it is implemented, it is useful to define all its knowledge in a Lean domain model. This domain model will also allow Lean practitioners to deepen their understanding of Lean.

The objective of the domain model is to represent all the knowledge of the Lean to understand it and unify its interpretation, and present a holistic definition of the Lean to be able to propose a generic Lean method based not only on a set of tools to be used in a predefined order.

To develop this domain model, it is necessary to identify the fundamental concepts of the Lean and define the relations between them. In this sense, a set of Lean concepts have been captured through a literature review of the Lean models, the definitions proposed for the Lean, and the interpretations of the authors.

At first, twelve concepts have been captured namely: Lean; Lean Description; Process; System; Problem; Sector; Domain; Operating Mode; Result; Objective; Principle and Tool. To help Lean practitioners choose the objectives to achieve, the principles to satisfy and the tools to use, and also to help them understand their usefulness, six additional concepts have been added: Quality Management, Risk Management, Resource Management, Time Management, Production Management and Relationship Management.

Table 2 indicates for each of these concepts, papers supporting their importance in understanding the Lean approach. 


\begin{tabular}{|c|c|}
\hline Concepts & References \\
\hline $\begin{array}{l}\text { Lean } \\
\text { description }\end{array}$ & $\begin{array}{l}\text { Albliwi et al. (2014); Danese et al. (2018); Maijala et al. (2018); Mazzocato, Savage, Brommels, Aronsson \& Thor } \\
\text { (2010); Stone (2012a) }\end{array}$ \\
\hline Process & $\begin{array}{l}\text { Aij \& Teunissen (2017); Bhamu \& Singh-Sangwan (2014); Cherrafi et al. (2017); Danese et al. (2018); de } \\
\text { Carvalho et al. (2017); de Freitas \& Costa (2017); Garza-Reyes (2015); Henrique \& Filho (2018); Maijala et al. } \\
\text { (2018); Mazzocato et al. (2010); Moraros et al. (2016); Raja-Sreedharan \& Raju (2016); Samuel et al. (2015); } \\
\text { Siyam, Wynn \& Clarkson (2015); Soliman \& Saurin (2017); Stone (2012a); Syltevik et al. (2017); Tasdemir \& } \\
\text { Gazo (2018); Woodnutt (2018) }\end{array}$ \\
\hline System & $\begin{array}{l}\text { Aij \& Teunissen (2017); Bhamu \& Singh-Sangwan (2014); Danese et al. (2018); Henrique \& Filho (2018); Maijala } \\
\text { et al. (2018); Mazzocato et al. (2010); Raja-Sreedharan \& Raju (2016); Samuel et al. (2015); Stone (2012a, 2012b); } \\
\text { Syltevik et al. (2017); Tasdemir \& Gazo (2018) }\end{array}$ \\
\hline Problem & $\begin{array}{l}\text { Albliwi et al. (2014); Bhamu \& Singh-Sangwan (2014); Cherrafi et al. (2017); Danese et al. (2018); de Carvalho et } \\
\text { al. (2017); Garza-Reyes (2015); Henrique \& Filho (2018); Laureani \& Antony (2017); Maijala et al. (2018); } \\
\text { Mazzocato et al. (2010); Soliman \& Saurin (2017); Tiamaz \& Souissi (2017) }\end{array}$ \\
\hline Sector & $\begin{array}{l}\text { Albliwi et al. (2014); Bhamu \& Singh-Sangwan (2014); Danese et al. (2018); Garza-Reyes (2015); Henrique \& } \\
\text { Filho (2018); Maijala et al. (2018); Mazzocato et al. (2010); Raja-Sreedharan \& Raju (2016); Tasdemir \& Gazo } \\
\text { (2018); Tiamaz \& Souissi (2017) }\end{array}$ \\
\hline Domain & $\begin{array}{l}\text { Albliwi et al. (2014); Bhamu \& Singh-Sangwan (2014); Danese et al. (2018); Henrique \& Filho (2018); Maijala et } \\
\text { al. (2018); Mazzocato et al. (2010); Soliman \& Saurin (2017); Syltevik et al. (2017); Tiamaz \& Souissi (2016, 2017) }\end{array}$ \\
\hline $\begin{array}{l}\text { Operating } \\
\text { mode }\end{array}$ & $\begin{array}{l}\text { Aij \& Teunissen (2017); Albliwi et al. (2014); Bhamu \& Singh-Sangwan (2014); de Freitas \& Costa (2017); } \\
\text { Henrique \& Filho (2018); Laureani \& Antony (2017); Moraros et al. (2016); Raja-Sreedharan \& Raju (2016); } \\
\text { Samuel et al. (2015); Soliman \& Saurin (2017); Syltevik et al. (2017); Woodnutt (2018) }\end{array}$ \\
\hline Result & $\begin{array}{l}\text { Albliwi et al. (2014); Bhamu \& Singh-Sangwan (2014); Cherrafi et al. (2017); Danese et al. (2018); de Carvalho et } \\
\text { al. (2017); Henrique \& Filho (2018); Laureani \& Antony (2017); Mazzocato et al. (2010); Moraros et al. (2016); } \\
\text { Raja-Sreedharan \& Raju (2016); Soliman \& Saurin (2017); Syltevik et al. (2017); Tasdemir \& Gazo (2018); } \\
\text { Woodnutt (2018) }\end{array}$ \\
\hline Objective & $\begin{array}{l}\text { Abdulmalek, Rajgopal \& Needy (2015); Albliwi et al. (2014); Bhamu \& Singh-Sangwan (2014); Cherrafi et al. } \\
\text { (2017); Garza-Reyes (2015); Henrique \& Filho (2018); Maijala et al. (2018); Samuel et al. (2015); Siyam et al. } \\
\text { (2015); Soliman \& Saurin (2017); Tasdemir \& Gazo (2018); Tiamaz \& Souissi (2017) }\end{array}$ \\
\hline Principle & $\begin{array}{l}\text { Abdulmalek et al. (2015); Aij \& Teunissen (2017); Bhamu \& Singh-Sangwan (2014); Cherrafi et al. (2017); } \\
\text { Danese et al. (2018); de Carvalho et al. (2017); Maijala et al. (2018); Raja-Sreedharan \& Raju (2016); Samuel et al. } \\
\text { (2015); Siyam et al. (2015); Soliman \& Saurin (2017); Stone (2012a, 2012b); Syltevik et al. (2017); Tiamaz \& } \\
\text { Souissi (2017) }\end{array}$ \\
\hline Tool & $\begin{array}{l}\text { Abdulmalek et al. (2015); Aij \& Teunissen (2017); Albliwi et al. (2014); Danese et al. (2018); de Carvalho et al. } \\
\text { (2017); Garza-Reyes (2015); Henrique \& Filho (2018); Laureani \& Antony (2017); Maijala et al. (2018); } \\
\text { Mazzocato et al. (2010); Raja-Sreedharan \& Raju (2016); Samuel et al. (2015); Siyam et al. (2015); Soliman \& } \\
\text { Saurin (2017); Stone (2012a); Syltevik et al. (2017); Tasdemir \& Gazo (2018); Tiamaz \& Souissi (2017); } \\
\text { Woodnutt (2018) }\end{array}$ \\
\hline $\begin{array}{l}\text { Quality } \\
\text { management }\end{array}$ & $\begin{array}{l}\text { Aij \& Teunissen (2017); Albliwi et al. (2014); Bhamu \& Singh-Sangwan (2014); Cherrafi et al. (2017); Danese et } \\
\text { al. (2018); Henrique \& Filho (2018); Honeycutt \& Keller (2018); Laureani \& Antony (2017); Lean Enterprise } \\
\text { Institute, Marchwinski, Shook \& Schroeder (2003); Liker (2004); Maijala et al. (2018); Mazzocato et al. (2010); } \\
\text { Miller (2012); Siyam et al. (2015); Tasdemir \& Gazo (2018) }\end{array}$ \\
\hline $\begin{array}{l}\text { Risk } \\
\text { management }\end{array}$ & $\begin{array}{l}\text { Aij \& Teunissen (2017); Cherrafi et al. (2017); Garza-Reyes (2015); Gnoni, Andriulo, Maggio \& Nardone (2013); } \\
\text { Laureani \& Antony (2017); Liker (2004); Maijala et al. (2018); Mazzocato et al. (2010, 2010); Mohammaddust, } \\
\text { Rezapour, Farahani, Mofidfar \& Hill (2017); Siyam et al. (2015) }\end{array}$ \\
\hline $\begin{array}{l}\text { Resource } \\
\text { management }\end{array}$ & $\begin{array}{l}\text { Abdulmalek et al. (2015); Aij \& Teunissen (2017); Liker (2004); Muriel (2015); Shah \& Ward (2003, 2007); Stone } \\
\text { (2012b); Tasdemir \& Gazo (2018) }\end{array}$ \\
\hline $\begin{array}{l}\text { Time } \\
\text { management }\end{array}$ & $\begin{array}{l}\text { Aij \& Teunissen (2017); Lean Enterprise Institute et al. (2003); Liker (2004); Maijala et al. (2018); Mazzocato et } \\
\text { al. (2010); Mize, Nightingale, Taneja \& Tonaszuck (2000); Muriel (2015); Shah \& Ward (2003); Siyam et al. } \\
\text { (2015); Tasdemir \& Gazo (2018) }\end{array}$ \\
\hline $\begin{array}{l}\text { Production } \\
\text { management }\end{array}$ & $\begin{array}{l}\text { Bhamu \& Singh-Sangwan (2014); Cherrafi et al. (2017); Lean Enterprise Institute et al. (2003); Miller (2012); } \\
\text { Mize et al. (2000); Muriel (2015); Shah \& Ward (2003); Tasdemir \& Gazo (2018); Womack \& Jones (1996) }\end{array}$ \\
\hline $\begin{array}{l}\text { Relationship } \\
\text { management }\end{array}$ & $\begin{array}{l}\text { Aij \& Teunissen (2017); Liker (2004); Maijala et al. (2018); Miller (2012); Muriel (2015); Spear (2004); Tasdemir \& } \\
\text { Gazo (2018); Womack \& Jones (1996) }\end{array}$ \\
\hline
\end{tabular}

Table 2. The captured Lean concepts 
Identifying the Lean concepts is not sufficient to build a Lean domain model. Therefore to define the rules that govern the interaction of the Lean concepts with each other is important:

- A model of the Lean is described using the terminology: "Lean Description".

- The Lean proposes a set of "Principles", "Tools" and "Objectives". These three elements represent the Lean axes.

- A "Principle", "Tool" and "Objective" belong to a "Category".

- A "Category" can be "Quality Management", "Risk Management", "Resource Management", "Time Management", "Production Management", or "Relationship Management".

- A Lean model is implemented according to an "Operating Mode" to produce a "Result".

- An "Operating Mode" may be "Specific" to a "Domain", "Sector" or "Problem".

- A "Result" corresponds to a subset of the "Objectives".

- An "Operating Mode" is applied to one or more "Processes".

- A "Process" is attached to a "System".

The domain model, illustrated in Figure 1, is a conceptual model that describes the knowledge of the Lean. This figure shows the relations between the Lean concepts and provides a clearer vision that improves and unifies its understanding.

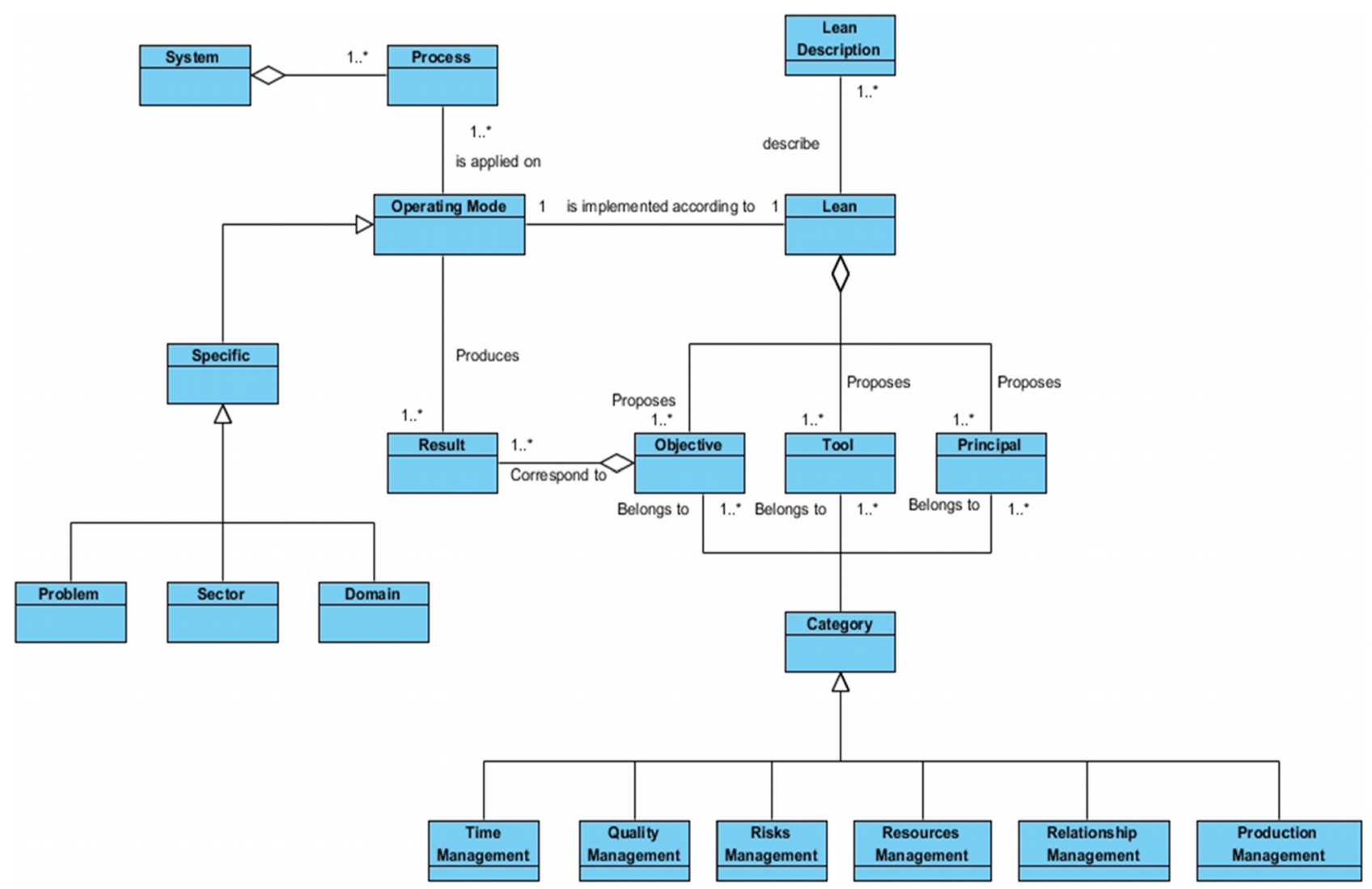

Figure 3. Domain Model of the Lean approach

\section{Using the Lean Domain Model in Developing a Lean Method}

The purpose of the Lean domain model is helping Lean practitioners understanding and defining the Lean approach better to develop effective Lean methods.

In this context, a Lean method was developed by Tiamaz, Lahboube and Souissi (2018) and is an extension of this work. This Lean method relied on this Lean domain model using the Lean concepts listed in Table 2. It's a generic 
method which consists of following nine phases (see Figure 4). Each phase is made up of a set of steps. To validate a phase, it is necessary to satisfy principles. And to validate a step, it is necessary to apply at least one tool (see Figure 5). This Lean method has been used to improve hospital processes of Moulay Ismail Hospital in Meknes, Morocco. They started with the traumatology process. This process receives more than 120 patients in a single day. Three consultation rooms are dedicated to this process. And he has 2 physician, 3 resident doctors and a receptionist.

This Lean method helped ensure the commitment of managers and staff, define the objectives to be achieved and the performance indicators to be evaluated, to help leaders select the appropriate process, map the process and analyze it (see Figure 6).

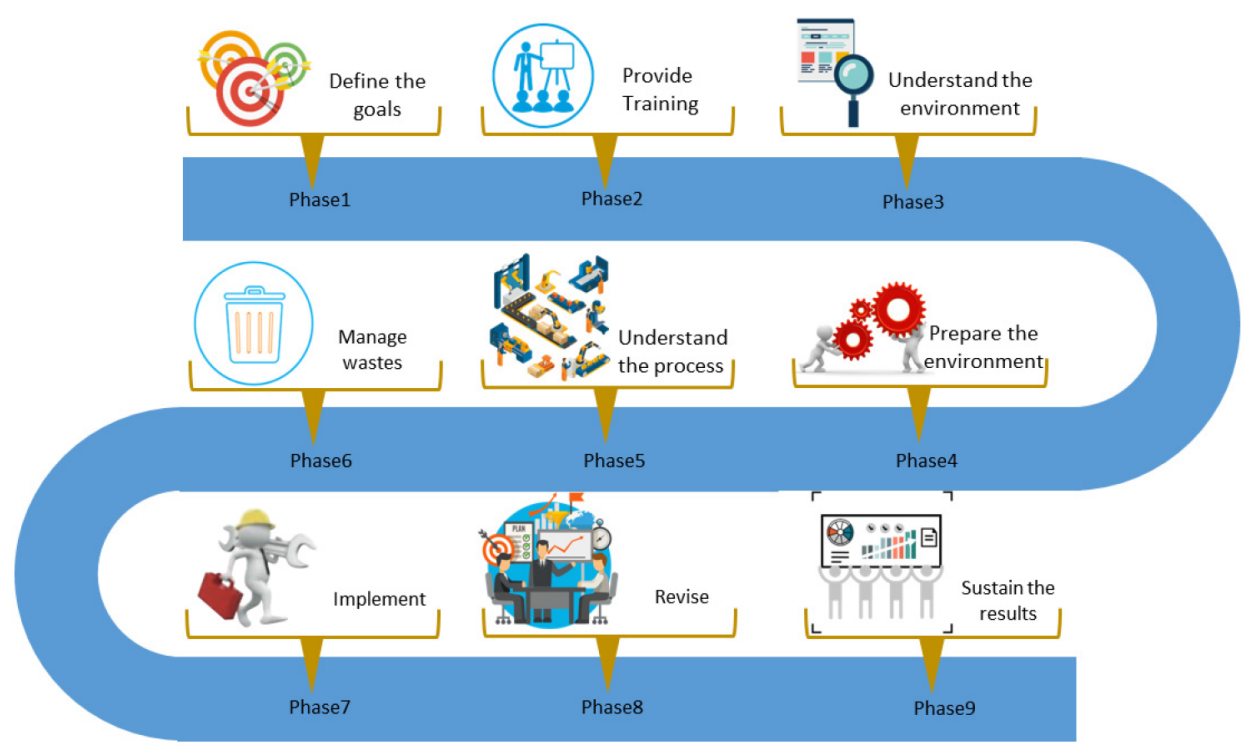

Figure 4. The proposed method

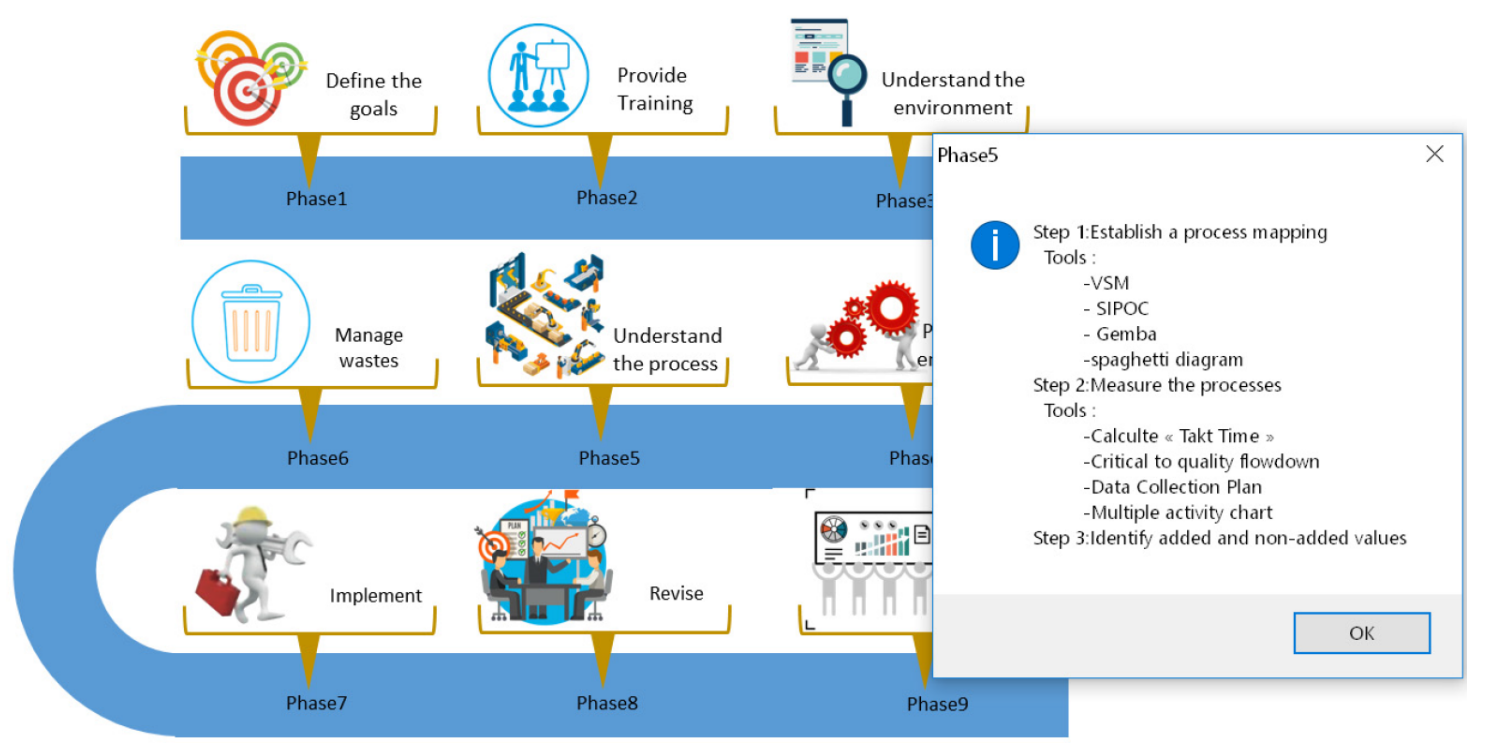

Figure 5. The steps and tools of phase 5 


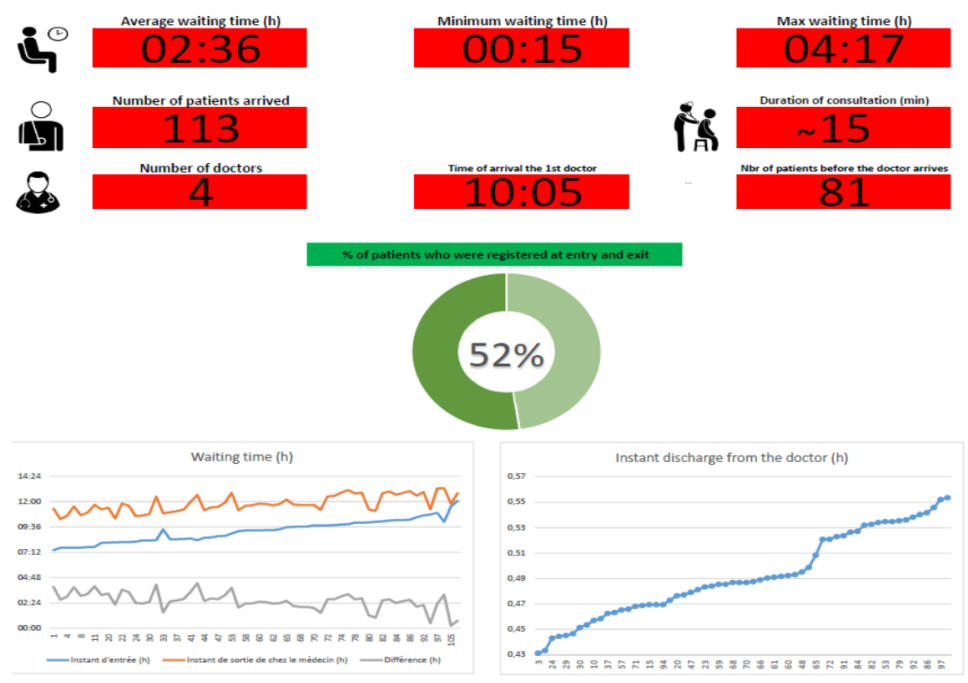

Figure 6. Process analysis (Tiamaz et al., 2018)

Taking into account all the knowledge of the Lean represented in the domain model during the development of a Lean method allowed to propose a personalized order of steps, according to the context of the target environment, to be followed also involving the use of tools and the verification of the Lean principles

\section{Conclusion and Future Work}

In the literature, the diversity of the definitions and the lack of a unified definition make difficult the understanding of the Lean. It is concluded, through a literature review, that one of the main failures, which meet companies to implement Lean in their processes is the non-understanding of Lean.

To get a standard definition of the Lean, it is necessary to separate Lean from the context in which will be implemented. This paper emphasized the study of the Lean concepts and their relations.

In this regard, the notation of the UML language is chosen to establish a domain model that represents the fundamental concepts of the Lean and the relations between them. These essential concepts are: Lean; Lean Description; Process; System; Problem; Sector; Domain; Operating Mode; Result; Objective; Principle and Tool. Other concepts are proposed to guide managers in their choice of the objectives, the principles Lean and the tools Lean: "Quality Management"; "Risk Management"; "Resource Management"; "Time Management"; and "Production Management" which are grouped under the concept "Category".

Several authors underlined the importance to have a holistic view of the Lean (Crute, Ward, Brown \& Graves, 2003; Graban, 2011; Henrique \& Filho, 2018; Holweg, 2007). However, for them to have a holistic view consists in implanting Lean in the whole system and not in the particular process. However, this paper is considered the system as being a concept of the Lean.

The modeling of the Lean by using the language of modeling UML allows facilitating the understanding of the Lean in a holistic way and not biased because of the specificities of the environments of the managers.

A generic Lean method has been developed by Tiamaz et al. (2018) and represents an extension of this work. This Lean method relied on the Lean domain model using the captured Lean concepts. It has been applied in the Moulay Ismail hospital in Meknes, Morocco.

The application of this Lean method will be finalized to compare the objectives achieved with the desired objectives identified in the first phase of this method.

\section{Declaration of Conflicting Interests}

The authors declared no potential conflicts of interest with respect to the research, authorship, and/or publication of this article. 


\section{Funding}

The authors received no financial support for the research, authorship, and/or publication of this article.

\section{References}

Abdulmalek, F.A., Rajgopal, J., \& Needy, K.L. (2015). A Classification Scheme for the Process Industry to Guide the Implementation of Lean. Engineering Management Journal, 18, 15-25.

https://doi.org/10.1080/10429247.2006.11431690

Aij, K.H., \& Teunissen, M. (2017). Lean leadership attributes: a systematic review of the literature. Journal of Health Organization and Management, 31, 713-729. https://doi.org/10.1108/JHOM-12-2016-0245

Albliwi, S., Antony, J., Halim-Lim, S.A., \& van der Wiele, T. (2014). Critical failure factors of Lean Six Sigma: a systematic literature review. International Journal of Quality \& Reliability Management, 31, 1012-1030. https://doi.org/10.1108/IJQRM-09-2013-0147

Belayutham, S., González, V.A., \& Yiu, T.W. (2016). Clean-Lean Administrative Processes: A Case Study on Sediment Pollution during Construction. Journal of Cleaner Production. https://doi.org/10.1016/j.jclepro.2016.02.091

Bhamu, J., \& Singh-Sangwan, K. (2014). Lean manufacturing: literature review and research issues. International Journal of Operations \& Production Management, 34, 876-940. https://doi.org/10.1108/IJOPM-08-2012-0315

Bhasin, S., \& Burcher, P. (2006). Lean viewed as a philosophy. Journal of Manufacturing Technology Management, 17, 56-72. https://doi.org/10.1108/17410380610639506

Caldera, H.T.S., Desha, C., \& Dawes, L. (2017). Exploring the role of lean thinking in sustainable business practice: A systematic literature review. Journal of Cleaner Production, 167, 1546-1565.

https://doi.org/10.1016/j.jclepro.2017.05.126

Casey, D. (2009). The Role of Change Leadership in an Operations Excellence Transformation Model. lulu.com.

Cherrafi, A., Elfezazi, S., Garza-Reyes, J.A., Benhida, K., \& Mokhlis, A. (2017). Barriers in Green Lean implementation: a combined systematic literature review and interpretive structural modelling approach. Production Planning \& Control, 28, 829-842. https://doi.org/10.1080/09537287.2017.1324184

Collar, R.M., Shuman, A.G., Feiner, S., McGonegal, A.K., Heidel, N., Duck, M. et al. (2012). Lean Management in Academic Surgery. Journal of the American College of Surgeons, 214, 928-936. https://doi.org/10.1016/j.jamcollsurg.2012.03.002

Crute, V., Ward, Y., Brown, S., \& Graves, A. (2003). Implementing Lean in aerospace-challenging the assumptions and understanding the challenges. Technovation, 23, 917-928. https://doi.org/10.1016/S0166-4972(03)00081-6

Danese, P., Manfè, V., \& Romano, P. (2018). A Systematic Literature Review on Recent Lean Research: State-of-theart and Future Directions: Literature Review on Recent Lean Research. International Journal of Management Reviens, 20, 579-605. https://doi.org/10.1111/ijmr.12156

de Carvalho, A., Granja, A., \& da Silva, V. (2017). A Systematic Literature Review on Integrative Lean and Sustainability Synergies over a Building's Lifecycle. Sustainability, 9, 1156. https://doi.org/10.3390/su9071156

de Freitas, J.G., \& Costa, H.G. (2017). Impacts of Lean Six Sigma over organizational sustainability:

A systematic literature review on Scopus base. International Journal of Lean Six Sigma, 8, 89-108.

https://doi.org/10.1108/IJLSS-10-2015-0039

Dennis, P. (2007). Lean Production Simplified (2nd ed.). New York: Productivity Press.

Dombrowski, U., \& Mielke, T. (2013). Lean Leadership - Fundamental Principles and their Application. Procedia CIRP, 7, 569-574. https://doi.org/10.1016/j.procir.2013.06.034

Duska, L.R., Mueller, J., Lothamer, H., Pelkofski, E.B., \& Novicoff, W.M. (2015). Lean methodology improves efficiency in outpatient academic Gynecologic Oncology clinics. Gynecologic Oncology, 138, 707-711.

https://doi.org/10.1016/j.ygyno.2015.07.001 
Forrester, P.L., Kazumi-Shimizu, U., Soriano-Meier, H., -Garza-Reyes, J.A., \& Cruz-Basso, L.F. (2010). Lean production, market share and value creation in the agricultural machinery sector in Brazil. Journal of Manufacturing Technology Management, 21, 853-871. https:// doi.org/10.1108/17410381011077955

Garza-Reyes, J.A. (2015). Lean and green - a systematic review of the state of the art literature. Journal of Cleaner Production, 102, 18-29. https://doi.org/10.1016/j.jclepro.2015.04.064

Gnoni, M.G., Andriulo, S., Maggio, G., \& Nardone, P. (2013). “Lean occupational” safety: An application for a Near-miss Management System design. Safety Science, 53, 96-104. https://doi.org/10.1016/j.ssci.2012.09.012

Graban, M. (2011). Lean Hospitals: Improving Quality, Patient Safety, and Employee Engagement (2nd ed.). New York: Productivity Press.

Henrique, D.B., \& Filho, M.G. (2018). A systematic literature review of empirical research in Lean and Six Sigma in healthcare. Total Quality Management \& Business Excellence, 0, 1-21. https://doi.org/10.1080/14783363.2018.1429259

Herron, C., \& Hicks, C. (2008). The transfer of selected lean manufacturing techniques from Japanese automotive manufacturing into general manufacturing (UK) through change agents. Robotics and Computer-Integrated Manufacturing, 24, 524-531.

Hines, P., Holweg, M., \& Rich, N. (2004). Learning to evolve: A review of contemporary lean thinking. International Journal of Operations \& Production Management, 24, 994-1011. https://doi.org/10.1108/01443570410558049

Holweg, M. (2007). The genealogy of lean production. Journal of Operations Management, 25, 420-437. https://doi.org/10.1016/j.jom.2006.04.001

Honeycutt, L.C., \& Keller, S.D. (2018). Effectiveness of the Lean process compared to other quality improvement initiatives on length of stay and wait times in healthcare organizations: a systematic review protocol. JBI Database of Systematic Reviews and Implementation Reports, 16, 12-20. https:/ / doi.org/10.11124/JBISRIR-2016-003304

Krafcik, J.F. (1988). Triumph of the lean production system. MIT Sloan Management Review, 30, 41.

Laureani, A., \& Antony, J. (2017). Leadership and Lean Six Sigma: a systematic literature review. Total Quality Management \& Business Excellence, 0, 1-29. https://doi.org/10.1080/14783363.2017.1288565

Lean Enterprise Institute, Marchwinski, C., Shook, J., \& Schroeder, A. (Eds.) (2003). Lean lexicon: a graphical glossary for lean thinkers. Brookline, Mass.: Lean Enterprise Institute.

Liker, J., Convis, G.L., \& Meskimen, J. (2014). The Toyota Way to Lean Leadership: Achieving and Sustaining Excellence Through Leadership Development. Audio CD. Brilliance Corp.

Liker, J.K. (2004). The Toyota way: 14 management principles from the world's greatest manufacturer. New York: McGraw-Hill.

Liker, J.K. (1997). Becoming Lean: Inside Stories of U.S. Manufacturers (1st ed.). Portland: Productivity Press

Maijala, R., Eloranta, S., Reunanen, T., \& Ikonen, T.S. (2018). Successful implementation of lean as a managerial principle in health care: a conceptual analysis from systematic literature review. International Journal of Technology Assessment in Health Care, 34, 134-146. https://doi.org/10.1017/S0266462318000193

Mazzocato, P., Savage, C., Brommels, M., Aronsson, H., \& Thor, J. (2010). Lean thinking in healthcare: a realist review of the literature. BMJ Quality \& Safety, 19, 376-382. https://doi.org/10.1136/qshc.2009.037986

Miller, R. (2012). The Shingo Principles of Operational Excellence-Model and Application Guidelines. Jon M. Huntsman School of Business-Utah State University.

Mize, J., Nightingale, D., Taneja, A., \& Tonaszuck, D. (2000). Transitioning to a Lean Enterprise: A Guide for Leaders (vol. I). Executive Overview.

Mohammaddust, F., Rezapour, S., Farahani, R.Z., Mofidfar, M., \& Hill, A. (2017). Developing lean and responsive supply chains: A robust model for alternative risk mitigation strategies in supply chain designs. International Journal of Production Economics, 183, 632-653. https://doi.org/10.1016/j.ijpe.2015.09.012 
Moraros, J., Lemstra, M., \& Nwankwo, C. (2016). Lean interventions in healthcare: do they actually work? A systematic literature review. International Journal for Quality in Health Care, 28, 150-165.

https://doi.org/10.1093/intqhe/mzv123

Mostafa, S., Dumrak, J., \& Soltan, H. (2013). A framework for lean manufacturing implementation. Production \& Manufacturing Research, 1, 44-64. https://doi.org/10.1080/21693277.2013.862159

Muriel, G. (2015). Amélioration des processus métier et utilisation de solutions de dématérialisation des processus. CXP

Orr, C. (2005). Lean Leadership in Construction. 13th International Group for Lean Construction Conference: Proceedings, 345.

Pavnaskar, S.J., Gershenson, J.K., \& Jambekar, A.B. (2003). Classification scheme for lean manufacturing tools. International Journal of Production Research, 41, 3075-3090. https://doi.org/10.1080/0020754021000049817

Pettersen, J. (2009). Defining lean production: some conceptual and practical issues. The TQM Journal, 21, 127-142. https://doi.org/10.1108/17542730910938137

Raja-Sreedharan, V., \& Raju, R. (2016). A systematic literature review of Lean Six Sigma in different industries. International Journal of Lean Six Sigma, 7, 430-466. https://doi.org/10.1108/IJLSS-12-2015-0050

Rohani, J.M., \& Zahraee, S.M. (2015). Production Line Analysis via Value Stream Mapping: A Lean Manufacturing Process of Color Industry. Procedia Manufacturing, 2, 6-10. https://doi.org/10.1016/j.promfg.2015.07.002

Rose, A.M.N., Deros, B.M., Rahman, M.A., \& Nordin, N. (2011). Lean manufacturing best practices in SMEs, in: Proceedings of the 2011 International Conference on Industrial Engineering and Operations Management (872-877).

Samuel, D., Found, P., \& Williams, S.J. (2015). How did the publication of the book The Machine That Changed The World change management thinking? Exploring 25 years of lean literature. International Journal of Operations \& Production Management, 35, 1386-1407. https://doi.org/10.1108/IJOPM-12-2013-0555

Shah, R., \& Ward, P.T. (2007). Defining and developing measures of lean production. Journal of Operations Management, 25, 785-805. https://doi.org/10.1016/j.jom.2007.01.019

Shah, R., \& Ward, P.T. (2003). Lean manufacturing: context, practice bundles, and performance. Journal of Operations Management, 21, 129-149. https://doi.org/10.1016/S0272-6963(02)00108-0

Siyam, G.I., Wynn, D.C., \& Clarkson, P.J. (2015). Review of Value and Lean in Complex Product Development. Systems Engineering, 18, 192-207. https://doi.org/10.1002/sys.21299

Soliman, M., \& Saurin, T.A. (2017). Lean production in complex socio-technical systems: A systematic literature review. Journal of Manufacturing Systems, 45, 135-148. https://doi.org/10.1016/j.jmsy.2017.09.002

Spear, S.J. (2004). Learning to lead at Toyota. Harvard Business Review, 82, 78-91.

Staats, B.R., Brunner, D.J., \& Upton, D.M. (2011). Lean principles, learning, and knowledge work: Evidence from a software services provider. Journal of Operations Management, 29, 376-390. https://doi.org/10.1016/j.jom.2010.11.005

Stone, K.B. (2012a). Four decades of lean: a systematic literature review. International Journal of Lean Six Sigma, 3, 112-132. https://doi.org/10.1108/20401461211243702

Stone, K.B. (2012b). Lean Transformation: Organizational Performance Factors that Influence Firms' Leanness. Journal of Enterprise Transformation, 2, 229-249. https://doi.org/10.1080/19488289.2012.664611

Sutari, O. (2015). Process Improvement Using Lean Principles on the Manufacturing of Wind Turbine Components - a Case Study. Materials Today: Proceedings, 2, 3429-3437. https://doi.org/10.1016/j.matpr.2015.07.318

Syltevik, S., Karamperidis, S., Antony, J., \& Taheri, B. (2017). Lean for airport services: a systematic literature review and agenda for future research. Int J Qual \& Reliability Mgmt, 35, 34-49. https://doi.org/10.1108/IJQRM-08-20160135

Tasdemir, C., \& Gazo, R. (2018). A Systematic Literature Review for Better Understanding of Lean Driven Sustainability. Sustainability, 10, 2544. https://doi.org/10.3390/su10072544 
Tiamaz, Y., Lahboube, F., \& Souissi, N. (2018). A Business Process Improvement Method. Presented at the Industrial Engineering and Operations Management Conference (14). Washington, D.C.

Tiamaz, Y., \& Souissi, N. (2018). Classification of the lean implementation procedures for improving the business processes. International Conference on Intelligent Systems and Computer Vision (ISCV) (1-6). https://doi.org/10.1109/ISACV.2018.8354019

Tiamaz, Y., \& Souissi, N. (2017). Lean Models Classification: Towards a Holistic View. International Journal of Industrial and Manufacturing Engineering, 11, 911-919.

Tiamaz, Y., \& Souissi, N. (2016). Meta-analysis of Lean case studies for the business process improvement. International Colloquium on Information Science and Technology (CIST) (4th ed). https://doi.org/10.1109/CIST.2016.7805038

Womack, J., Jones, D.T., \& Roos, D. (1990). The machine that changed the world. New York, NY: Rawson Associates.

Womack, J.P., \& Jones, D.T. (2003). Lean Thinking: Banish Waste and Create Wealth in Your Corporation, Revised and Updated (2nd ed.). New York: Free Press.

Womack, J.P., \& Jones, D.T. (1996). Lean thinking: Banish waste and create wealth in your organisation. New York, NY: Simon and Shuster.

Woodnutt, S. (2018). Is Lean sustainable in today's NHS hospitals? A systematic literature review using the meta-narrative and integrative methods. International Journal for Quality in Health Care.

https://doi.org/10.1093/intqhc/mzy070

Journal of Industrial Engineering and Management, 2019 (www.jiem.org)

\section{(1) $(\$$}

Article's contents are provided on an Attribution-Non Commercial 4.0 Creative commons International License. Readers are allowed to copy, distribute and communicate article's contents, provided the author's and Journal of Industrial Engineering and Management's names are included. It must not be used for commercial purposes. To see the complete license contents, please visit https://creativecommons.org/licenses/by-nc/4.0/. 